\title{
ALTERATIONS OF SERUM ENZYMES IN PROTEIN ENERGY MALNUTRITION
}

Dr. A. K. Tadas, Dr. A. N. Jadhao, Dr. S. A. Tadas.
1. Associate Professor, Department of Biochemistry, Government Medical College, Nagpur.
2. Junior Resident, Department of Biochemistry, Government Medical College, Nagpur.
3. Assistant Professor, Department of Physiology, Government Medical College, Nagpur.

\section{CORRESPONDING AUTHOR,}

Dr. A.K. Tadas, 437 A, Hanuman Nagar,

Nagpur - 440009,

E-mail: aruntadas@rediffmail.com,

Ph: 09423100663.

ABSTRACT: OBJECTIVES: To study the correlation of serum enzymes (alkaline phosphatase, aspartate aminotransferase, alanine aminotransferase, amylase) abnormalities in protein energy malnutrition and to assess their clinical significance. MATERIAL AND METHOD: 30 cases of PEM admitted to the pediatric wards of Government Medical College and Hospital, Nagpur were studied from 5 Jan 2011 to 15 August 2011. 30 age and sex matched controls were selected from children of normal weight for age attending OPD or wards. All the clinical details, along with the relevant clinical history were noted. Venous blood sample was collected for estimation of alkaline phosphatase, aspartate aminotransferase, alanine aminotransferase, and amylase. RESULTS AND OBSERVATIONS: Patients with PEM had reduced serum alkaline phosphatase. Amylase was found to be reduced in kwashiorkor while it remained unchanged in marasmus. Increase in aspartate aminotransferase, alanine aminotransferase was found in PEM. Serum amylase in kwashiorkor is lower than marasmus. DISCUSSION: In patients with PEM, we found higher levels of AST and ALT , as there is increased tissue breakdown in PEM to metabolise the amino acids released by protein catabolism, the process of transamination is enhanced leading to increased activity of related enzymes AST and ALT. Reduced serum Alkaline phosphatase may be due to impairment of protein synthesis. Many of these alternations of enzymes may be due to metabolic readjustment resulting from protein deficiency.

KEY WORDS: Protein Energy Malnutrition, Enzymes, Alanine Aminotransferase, Aspartate aminotransferase,Alkaline phosphatase,Amylase.

INTRODUCTION: The World Bank estimates that after Bangladesh, India is ranked 2nd in number of children suffering from malnutrition (in 1998), where $47 \%$ of the children exhibit a degree of malnutrition. The prevalence of underweight children in India is among the highest in the world, and is nearly double that of Sub-Saharan Africa with dire consequences for mobility, mortality, productivity and economic growth ${ }^{1}$. The UN estimates that 2.1 million Indian children die before reaching the age of 5 every year - four every minute - mostly from preventable illnesses such as diarrhoea, typhoid, malaria, measles and pneumonia. Every day, 1,000 Indian children die because of diarrhoea alone ${ }^{1}$. According to the 1991 census of India, it has around 150 million children, constituting $17.5 \%$ of India's population, who are below the age of 6 years.

Enzymes being proteins, disturbances in their functions and levels in the body are expected to occur in PEM of any severity ${ }^{2}$. Our aim is to determine if any biochemical 
parameters could be helpful in early diagnosis of PEM and to understand the correlation of abnormalities of serum enzymes (alkaline phosphatase, aspartate aminotransferase, alanine aminotransferase, amylase) in protein energy malnutrition and to assess their clinical significance.

METHODS: The study was carried out in 60 children of six months to five years of age of both sexes. Group A includes 30 children suffering from various grades of PEM were selected as experimental group and excludes hepatobiliary and other disease by history, physical examination and investigations i.e. serum bilirubin and ultrasonography of abdomen.. Group B includes 30 age and sex matched healthy children. The exclusion criteria for group A was children suffering from any systemic disease other than PEM, but minor association like diarrhoea, cough and cold was included in the study .Protocol of study had been accepted by the Ethical Committee. After taking the informed consent from the mothers and guardians they were asked a pre-coded questionnaire to collect data related to the study.

By aseptic precautions $5 \mathrm{ml}$ of blood was drawn from patient's dorsal hand or wrist vein and collect with a smaller gauge needle (22g or $23 \mathrm{~g}$ ).Serum was separated immediately by centrifugation at $3000 \mathrm{rpm}$ for $10 \mathrm{~min}$. Estimation of enzyme was carried out immediately

METHODS: Enzymes were estimated by kinetic method.

\section{ALKALINE PHOSPHATASE BY KIT METHOD ${ }^{8}$}

PRINCIPLE: Alkaline phosphatase cleaves p-nitrophenyl phosphate (p-Npp) into p-nitrophenol and phosphate. p-nitrophenol is a yellow colour compound in alkaline medium and absorbs light at $405 \mathrm{~nm}$. The rate of increase in absorbance at $405 \mathrm{~nm}$ is proportional to alkaline phosphatase activity in specimen.

p-nitrophenyl phosphate $\rightarrow$ p-nitrophenol + phosphate

\section{ASPARTATE AMINOTRANSFERASE(AST) BY KIT METHOD 9}

PRINCIPLE:- L-Asparate $+\alpha$-ketoglutarate $\longrightarrow$ AST $\quad$ Oxaloacetate + L-Glutamate

Oxaloacetate $+\mathrm{NADH}+\mathrm{H}^{+} \quad \mathrm{MDH} \longleftarrow \mathrm{L}-\mathrm{Malate}+\mathrm{NAD}^{+}$

This conversion of NADH to $\mathrm{NAD}^{+}$is proportional to the concentration of AST in serum and is measured at $340 \mathrm{~nm}$, as rate of decrease in absorbance.

\section{ALANINE AMINOTRANSFERASE(ALT) BY KIT METHOD ${ }^{10}$}

PRINCIPLE:-SGPT catalses the transfer of amino group from L-alanine to 2-oxoglutarate with the formation of pyruvate and L-glutarate.The pyruvate so formed is allowed to react with $\mathrm{NADH}$ to produce L-lactate.The rate of this reactioin is monitored by an indicator reaction coupled with LDH(lactate dehydrogenase) in the presence of NADH.The oxidation of NADH in this reaction is measured as a decrease in the absorbance of NADH at $340 \mathrm{~nm}$, which is proportional to SGPT activity

L-alanine + 2-oxoglutarate ALT__ pyruvate + L-glutamate

Pyruvate + NADH LDH_Ltetate + NADH

AMYLASE BY KIT METHOD 11

PRINCIPLE: Amylase test involves use of a chromogenic substrate Gal G2 - $\alpha$ CNP (2-chloro -4nitrophenyl linked with galactosylmaltosid).The direct action of amylase with this substrate results in the release of more than $90 \%$ of 2 -chloro -4-nitrophenol, which can be monitored by 
kinectic assay at $405 \mathrm{~nm}$. The increase in absorbance is directly proportional to the amylase activity in sample.

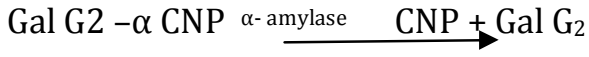

\section{STATISTICAL ANALYSIS}

$>$ Data was analysed using primer software..

$>$ The values were quoted in the form of mean \pm standard deviation. Statistical analysis of the result was done by unpaired student " $t$ "-test.

$>$ The $\mathrm{p}$ value $(\mathrm{p}<0.05)$ was used to find the significance.

RESULTS: In our study, the mean values of transaminases (ALT\&AST) levels were significantly increased in PEM than in controls ( table I).

Table I .Comparision of ALP, AST and ALT Between group A (PEM) and Group B (Control)

\begin{tabular}{|l|l|l|l|}
\hline Enzyme (units) & $\begin{array}{l}\text { Group A PEM }(\mathrm{N}=30) \\
. \text { Mean } \pm \text { SD }\end{array}$ & $\begin{array}{l}\text { Group B CONTROL ( N =30 ) } \\
\text {.Mean } \pm \text { SD }\end{array}$ & P value \\
\hline ALP (IU/L) & $6.77^{* * *} \pm 0.23$ & $12.82 \pm 0.27$ & $<0.001$ \\
\hline AST(IU/L) & $73.43^{* * *} \pm 2.73$ & $31.83 \pm 1.16$ & $<0.001$ \\
\hline ALT(IU/L) & $82.96^{* * *} \pm 2.11$ & $29.43 \pm 0.90$ & $<0.001$ \\
\hline
\end{tabular}

The mean values of Alkaline phosphatase leve(ALP) was significantly higher in PEM than controls shown in table I.

Table II. Comparison of serum amylase between group A (Kwashiorkor) and Group B (Control)

Kwashiorkor

\begin{tabular}{|l|l|l|l|}
\hline Enzyme (units) & PEM ( $\mathrm{N}=17)$ & CONTROL $(\mathrm{N}=17)$ & P value \\
\hline AMYLASE (U/L) & $47.64^{* * *} \pm 10.97$ & $80.17 \pm 9.04$ & $<0.001$ \\
\hline
\end{tabular}

The mean values of serum amylase was significantly higher in kwashiorkor than controls ( table II).

Table III. Comparision of serum amylase between group A (marasmus) and Group B (Control)

Marasmus

\begin{tabular}{|l|l|l|l|}
\hline Enzyme (units) & PEM ( N =13) & CONTROL ( N =13 ) & P value \\
\hline AMYLASE (U/L) & $79.30^{* *} \pm 7.66$ & $81 \pm 6.97$ & $>0.05$ \\
\hline
\end{tabular}

The mean value of serum amylase was significantly higher in marasmus than controls ( table III). 
DISCUSSION: In our study, serum AST and ALT levels in PEM were significantly higher than that of controls. Similar findings were reported by Kumari R et $\mathbf{a l}^{2}$ that the mean serum values of aspartate aminotransferase, alanine aminotransferase in patients with PEM were significantly higher than the controls. Similerly our findings also mimics with study conducted by McLean AEM 3 in his study he showed that the activity of alanine aminotransferase in serum was increased, and that greater the value greater was the mortality. Our finding also resembles with Rao $\mathbf{A}$ et al 4 in their study, the aminotransferase elevated. Our study also coinside with Karmacharya $\mathbf{K}$ et $\mathbf{a l}^{5}$.It is suggested that the moderate rise in aminotransferases found in PEM is not due to damage to the liver. There is increased metabolism of amino acids released from increased tissue breakdown. Thus process of transamination is enhanced leading to increased activity of ALT and AST ${ }^{13}$.

Serum alkaline phosphatase level in PEM was significantly lowered than controls. Similar findings were reported by Karmacharya $\mathbf{K}^{5}$,Singh R.S et al ${ }^{7}$ and Schwartz $\mathbf{R}^{6}$ In PEM, lowering of serum values of ALP could be explained on the basis of generalized protein deficiency leading to impaired synthesis. Failure of bone growth may also contribute to the lowering ALP value ${ }^{14}$.

Serum amylase in kwashiorkor was lower than marasmus. The low levels of amylase in serum are accompanied by a reduced output of pancreatic enzymes into the gut, as pancreas is the first organ to get damaged leading to degeneration and atrophy ${ }^{12}$.

CONCLUSION: The present study shows that any type of PEM can be associated with alteration in levels of serum enzymes. Many of these abnormalities are probably due to metabolic readjustment resulting from PEM. The ultimate practical objective of the enzyme studies which have been described is to help in the management of PEM, as it is often supposed that this is a practical problem for which new scientific knowledge is not needed.

Above mentioned view is a superficial. We are faced with the possibility that 'marginal malnutrition' in childhood may cause a permanent impairment, and yet we cannot recognize or define this 'marginal malnutrition' with any precision. But this can be done with the enzyme studies described above.

\section{REFERENCES:}

I. 1."World Bank Report". Source: The World Bank (2009). http://web.worldbank.org/WBSITE/EXTERNAL/COUNTRIES/SOUTHASIAEXT/ 0,,contentMDK:20916955 pagePK:146736 piPK:146830 theSitePK:223547,0 0.html. Retrieved 2009-03-13. "World Bank Report on Malnutrition in India"

II. Kumari R., Rao Y.N., Talukdar B. et.al., Serum Enzyme Abnormalities in Protein Energy Malnutrition, Indian Pedtr 1993;30:469-473.

III. McLean AEM. Heptic Failure in Malnutrition. Lancet 1962,2; 1292-1294.

IV. Rao A., Cherian A., Onuora C.U. Suvarnabai P.C. Serum Amonitransferases and rglutamyl transferase in Protein Energy Malnutrition. Trop Geogr Med. 1985, 37:11-14.

V. Karmacharya K, Islam MN, Role of Serum Alanine Aminotransferase Aspartate Aminotransferase and Alkaline Phosphatase in Early Detection of Protein Energy 
VI. Malnutrition, J. Nepal Paediatr. Soc. Vol 27, No. 2.

VII. Schwartz R. Alkaline Phosphatase Activity in Kwashiorkor, Journal Clin Path 1956, 9:333

VIII. Singh R.S, Agrawal S.P. \& Dikshit S.K., Serum Enzymes in Nutritional Muscular Wasting. Ind J. Pedtr. 1972, 39:299: 383-388.

IX. 8.Autozyme new alkaline phosphatase enzymatic, manufactured by Accurex Biomedical private limited, Thane, India. Kit.

X. 9.Autozyme new aspartate aminotransferase enzymatic, manufactured by Accurex Biomedical private limited, Thane, India. Kit.

XI. Autozyme alanine aminotransferase enzymatic, manufactured by Accurex Biomedical private limited, Thane, India. Kit.

XII. Autozyme infinite amylase enzymatic, manufactured by Accurex Biomedical private limited, Thane, India. Kit. 